\title{
Ficção e Realidade em Romance Haitiano
}

\section{Tania Franco Carvalhal}

Receptivo à força e ao encantamento da moderna ficção hispanoamericana, o leitor brasileiro é agradavelmente surpreendido quando entra em contato com a literatura do Haiti, que nos introduz, como aquela, num universo mágico, sem perder, no entanto, os vínculos com a realidade.

Se os temas explorados, aliados à estranha conjunção de magia, opressão e sensualidade que se expressa nestes textos os aproximam, a afinidade entre eles se dá ainda na busca de soluções formais para facilitar o ingresso do leitor em territórios desconhecidos, embora próximos àquele em que vive.

Ao vermos emergir nessas obras idênticas inquietações, constatamos que as distâncias geográficas são pouco relevantes no domínio literário quando os conflitos que o sustentam se equivalem. No caso, manifestam dramas que são os da América, considerada num sentido bem amplo, independente de serem produto de colonização francesa, luso-hispânica ou inglesa.

E o que ocorre com a leitura de $O$ Pau de $\mathrm{Sebo}^{1}$ do haitiano René Depestre, recém traduzido para o português.

Romance curto, denso, o livro de Depestre, não obstante sua marcada origem, tem natureza "americana". Delimitar essa identidade, entretanto, não significa restringir seu alcance. Ao contrário, esse romance haitiano, mesmo construído nas malhas da História

1. REN DEPESTRE. O Pau de Sebo. RJ. Marco Zero, maio de 1983 (trađução de Estela dos Santos Abreu e Maria Wanda M. de Andrade). 
datada, tem como matéria o homem, as opressões políticas a que se vê sujeito e as saídas que encontra para elas.

Não seria incorreto dizer que sua narrativa parece ter um pé no inventado e outro no real. Isso porque, ao desencadear o relato, o faz com o "era uma vez" convencional, anexando-lhe de pronto o componente alegórico que o vai caracterizar.

Tal peculiaridade já é pressentida na nota introdutória que antecede a narração mas a integra. Nesta, o autor enfatiza o caráter ficcional da narrativa e estimula-nos a pensar nas relações que aquilo que vai ser contado mantém com fatos acontecidos em algum lugar. Assim, o "Grande País Zacarino", cenário da ação, é uma terra imaginária, no dizer do autor. Para ele, qualquer similitude, próxima ou longínqua, com nomes, situações, lugares, sistemas, rodas dentadas de ferro ou de fogo, ou qualquer outro escândalo da vida real, só pode ser fruto de coincidência, 'não apenas fortuita mas extremamente escandalosa'".

A ênfase dada às aproximações, a insistência em negá-las e a adjetivação redundante neste trecho acentuam a ironia que o marca e que transparecerá ainda ao longo da narrativa, igualmente caracterizando-a. Mas, sobretudo, põem em relevo a intenção de falar de outra coisa além do objeto primeiro do enunciado. Toda a introdução nos diz que se trata de uma maneira figurada de falar e que as palavras devem ser lidas em sentido alegórico ou duplo.

A breve nota inicial pertence, portanto, ao plano do autor, pois que o coloca em contato direto com o leitor, na condição de um alerta sobre o que irá ler nas páginas seguintes.

Mas, iniciado o relato, quando a ironia dominante nas primeiras passagens que situam o contexto da ação se dilui, a leitura passa a ser envolvente e a narrativa ganha interesse em si mesma.

Tudo é tão convincente que esquecemos de que ela serve para ilustrar outra coisa explicitamente. A história da personagem central - Henri Postel - é contada por um narrador que se omite, reduzindo-se a uma terceira pessoa fora do relato que dá amplo espaço para os diálogos entre as personagens de maneira a torná-las vivas e presentes. A narrativa também nos permite entrar na intimidade de Henri Postel, pois o acompanhamos de dois ângulos, a pensar e a agir. 
Por isso, não estranhamos que intervenha na narração um discurso reflexivo, que nasce na consciência da personagem, quando ela toma uma decisão importante para a sequiência dos acontecimentos. $\overline{\mathrm{E}}$ o pensamento de Postel que se verbaliza nessa passagem:

"Se o que vais fazer tem algum sentido, a imaginação do povo será bem capaz de perceber. Tua função não é desenhar alegorias no céu da cidade, nem bancar um novo Postel para milhares de espectadores. A droga da tua vida não é um espetáculo. Não estás à cata de méritos solitários, nem és um desses intelectuais que, incapazes de situar-se na massa, chafurdam sem parar nos símbolos e fábulas da consciência moral. Vais trabalhar por teus negros, com eles" (p. 30).

No contexto em que surge, tal discurso vem impregnado do espírito de negritude com afirmação, necessidade de encontrar seu lugar no mundo e nele atuar diretamente. Mas aqui negritude, como apontou Maximilien Laroche em estudo recente, ${ }^{2}$ tem o sentido amplo de nacionalismo. Não significa oposição de negros a brancos, nem de colonizado a colonizador, mas é o sentimento de revolta contra qualquer forma de escravidão, do homem oprimido por outro homem, seu igual.

$\mathbf{E}$ aí reside o núcleo alegórico do relato: a história de Henri Postel, além da conquista individual, simboliza a reação coletiva contra a opressão de um regime que escraviza e anula. Em tal situação, a busca pessoal logra o significado de procura de identidade nacional. Por isso, todas as personagens que intervêm na narrativa representam o povo em suas múltiplas variantes. Reunidos em torno de idêntica intenção libertária, embora adotem formas de atuar diversas, são elas que introduzem no narrado os traços peculiares a uma dada cultura: seus cultos, medos e superstições. Assim, o discurso narrativo se embebe de sensualismo ambiental, matizando-se de forte e característica cor local. Por outro lado, o

2. «Negritude e Nacionalismo», estudo de M. Laroche, apresentado no Congresso sobre o pensamento político latino-americano, em Caracas, junho
de 1983. 
humor nele dominante lhe confere o traço liberatório, aglutinando-se aos mitos, ao popular e absorvendo o cotidiano, numa realização que pode ser rastreada, na literatura brasileira, em Macunaíma, de Mário Andrade, na obra de Oswald de Andrade e mesmo na poesia de Raul Bopp.

Ressalta, então, uma das singularidades deste livro de Depestre: a habilidade com que se resolve, por meio de um discurso narrativo equilibrado com o primitivismo, a magia e o erotismo do narrado, a articulação do real com sua representação ficcional.

Isso o converte num livro "saboroso", como o qualificou um de seus melhores críticos, Alain Bosquet.

Mesmo que as personagens tenham uma função que se pode dizer representativa, cada uma ganha vida própria ao se movimentarem num ambiente onde sobrevivem, em inusitada convivência, religiosidade e magia.

O que impressiona é a naturalidade com que o "maravilhoso" invade o real, nele se amalgamando. Por isso, a vida das personagens é regida por elas mesmas e pela intervenção dos deuses do vodu.

No terreno das crendices não há distinção entre os homens, todos delas se valem como proteção ou arma de ataque. Até aqueles, como Postel, que por uma postura intelectual intentam conservar um certo distanciamento dos fenômenos aparentemente inexplicáveis, não o conseguem. Certos acontecimentos dispensam a compreensão racional e, sobretudo, não são inquietantes porque se integram com naturalidade no cotidiano. O "maravilhoso" é inerente a este universo que o absorve como conduta normal.

Nesse contexto, não apenas os homens se disputam mas também as divindades que os apóiam entram em confronto. São as entidades míticas dos loás, certo poder sobrenatural, que permite àqueles que o recebem realizar façanhas extraordinárias.

Compreende-se, então, que num país atemorizado do Caribe, no povo subjugado pela ditadura e naqueles que a exercem, conserva-se inalterada a religião que, como marca das origens, liga a todos indistintamente. E é ela que constitui um dos elementos substantivo do narrado, conferindo-lhe peculiaridade e neutralizando, no interior da narrativa, os limites entre o real e "o maravilhoso". Este 
funciona no relato como "uma revelação privilegiada da realidade", para empregar uma expressão de Alejo Carpentier.

Estamos, sem dúvida, em contato com uma das manifestações do "real maravilhoso americano", experimentando o sincretismo cultural que singulariza uma realidade histórica não apreensível por critérios convencionais do pensamento ocidental. Em tal clima o leitor sufoca e vive a atmosfera de expectativa geral que perpassa o romance.

Nesse sentido, a obra de Depestre se aproxima das de Alejo Carpentier, de Rulfo, de Astúrias, ou seja, de realizações que resgatam na ficção a conjunção de elementos díspares, oriundos de culturas diversas para constituirem uma nova realidade, resultante dessa fusão. $\overline{\mathrm{E}}$ a América que se expressa porque se constrói nessa ficção paradoxalmente verdadeira.

A par desses aspectos, há outro dado interessante no livro de Depestre: a sua original composição que, apesar da simplicidade estrutural do início, adquire complexidade crescente.

Nas páginas finais, concluído o relato da transformação de Henri Postel, a narrativa bruscamente se desdobra, assumindo outro feitio.

O narrador, até então ausente do relato em neutra onisciência, nele se integra para historiar, num "Epílogo", a repercussão no mundo inteiro dos fatos que acabara de narrar. Como se fosse um novo personagem, ele conta a história do livro, como e por que o escrevera, baseado nas notas e comentários daqueles que o tinham vivido. Deste modo, a narração impessoal cede lugar a outra, na primeira pessoa, criando um novo plano narrativo, contraposto ao anterior.

É curioso como esse recurso dá à parte já lida maior densidade, embora acentue seu caráter de ficção. No entanto, o "real" em que se situa o narrador também é uma "invenção", contribuindo assim para a diluição das fronteiras entre os dois planos.

Com esse acréscimo, a narrativa precedente se dilata em significados, possibilitando outras interpretações. Percebemos que a alteração estrutural do romance nos permite ler a história de Postel, sua recuperação, não apenas como alegoria de um movimento de liberação coletivo mas ainda como correspondendo ao drama do 
narrador, a quem cabia escrever o livro. Ao colocar em cena a situação de quem o elabora, o texto questiona-se a si mesmo, propondo indagações implícitas como "o que escrever, como e por que" fazê-lo.

Assim, desvelando a "feitura" do livro, a figura do narrador será um símile da personagem central: como Postel, também ele tinha uma tarefa a cumprir, devia valer-se da ficção para expressar a realidade. Graças a isso, é possível ler o discurso da consciência de Postel, antes transcrito parcialmente, como algo que pudesse ser pensado indistintamente pelos dois.

O comprometimento do narrador com a história e com sua própria atuação fica manifesto quando diz, no epílogo:

"eu tinha enfim sobre a minha mesa, mais palpáveis do que um manuscrito encontrado numa garrafa, as bases e ferramentas necessárias para replantar a história de Henri Postel nas zonas férteis da minha imaginação".

Nessa rápida passagem, vincula matéria e ofício como irá fundir, no relato, ficção e realidade. Se os dois primeiros são os recursos de que dispõe para cumprir sua função, as outras duas são os elementos com que joga na própria obra.

Estamos em pleno eixo da construção de Depestre. Antes de tudo, cabe-lhe "replantar uma história nas zonas férteis de sua imaginação". Isso significa que devia esquecê-la para que fosse possível imaginá-la. Esse "replantar" pode ser lido como a conversão do real em ficção de modo a instaurar com essa uma nova realidade capaz de representar território tão controverso, mágico e oprimido. Confere-lhe, portanto, o caráter de "inventado".

Ficam claras assim as intenções ironicamente expressas no início do livro. Ao dizer ali que a obra não era uma "crônica histórica", nem "autobiográfica" nem mesmo "roman à clefs", o autor desejava que o leitor enveredasse para o terreno das ambigüidades, característico da Ficção. Mistura no começo, real e imaginário para obter um leitor disposto a envolver-se na narrativa, podendo experimentá-la em si mesma, com intensidade. Se descompromete aparentemente o narrado com o real, a princípio, é porque quer, ao final, amarrá-lo a ele em definitivo. 
$\overline{\mathrm{E}}$ o que acontece quando lemos as páginas que fecham o volume, último desdobramento narrativo.

Após o epílogo, como se nada mais houvesse a contar, novamente o narrador se omite, cedendo lugar a uma das personagens que enumera, numa carta, os fatos ocorridos num tempo posterior ao do narrado. Este teria sido o documento que o estimulara a realizar o livro e aí consta como um anexo.

Trata-se, sem dúvida, de mais um recurso para conferir ao que foi contado ainda maior credibilidade. Além disso explicita melhor a atuação do narrador. Há neste texto conclusivo um adensamento de referências que remetem, ao mesmo tempo, ao plano do narrador e ao real prosaico, a tudo subjacente.

Vê-se que somente em narrativas como essa, onde ficção e realidade estão tão intimamente mescladas, é possível a uma personagem que viveu a história migrar para fora dela, ao lado do narrador. Assim, a personagem atua como se saísse da tela principal e se incorporasse a um plano de fundo, domínio da ação-denúncia.

Como se observa, há uma estrutura de montagem que é quase cinematográfica com a superposição de vários planos narrativos, demarcados principalmente pela diferenciação de discurso. Esse procedimento contribui para a diluição das fronteiras entre ficção e realidade, acentuando as relações de compromisso entre ambas.

Por isso, esta obra, além de difundir entre nós uma literatura pouco conhecida como a haitiana, se destaca no acervo da prosa de ficção contemporânea por sua singular construção narrativa onde são repensadas as articulações da realidade com as formas de sua representação.

$\mathrm{E}$ é preciso ressaltar que o engenho da composição não interfere na fluência da leitura, ao contrário, é tão consistente a narrativa que, fechado o livro de Depestre, ela se projeta, em outro domínio, pois imaginação e palavra que a corporifica ecoam em nossa realidade, esclarecendo-a.

outubro de 1983 